\title{
Feeding habits of Dermatonotus muelleri (Anura, Microhylidae) from a semiarid region in Pernambuco state, Northeastern Brazil
}

\author{
H. T. S. Machado * (D), K. C. Araújo (D), R. A. Benício $^{b}$ (D) and R. W. Ávila ${ }^{a}$ (D) \\ ${ }^{a}$ Universidade Federal do Ceará - UFC, Departamento de Biologia, Programa de Pós-Graduação em Ecologia e Recursos \\ Naturais, Fortaleza, CE, Brasil \\ bUniversidade Regional do Cariri - URCA, Departamento de Química Biológica, Programa de Pós-Graduação em \\ Diversidade Biológica e Recursos Naturais, Laboratório de Herpetologia, Crato, CE, Brasil \\ *e-mail: heitortdsm@gmail.com
}

Received: November 6, 2019 - Accepted: April 23, 2020 - Distributed: November 30, 2021

Anurans control a great diversity of prey populations presenting an important role in the control of insects (including pest proliferation), and also as preys in the reptiles, birds, and mammals diet (Bernarde, 2012), being also considered generalists and opportunists predators (Duellman and Trueb, 1994). However, some anuran species have wide distribution and their diet might vary according to the physiognomy (Pacheco et al., 2017), thus, it is crucial to understand the feeding preferences in each habitat and the changes according to the environmental differences.

Among the Microhylidae species, Dermatonotus muelleri (Boettger, 1885) is a widely distributed semi fossorial frog considered a forelimbs-head-first burrower (Nomura et al., 2009). In Brazil, this species' feeding habits were recorded for the Central-Western (Vaz-Silva et al., 2003), Southeastern (Menin et al., 2015), and Northeastern Regions (Leite-Filho et al., 2015; Caldas et al., 2019), but data from the semi-arid was still missing. Here, we present the feeding habits of $D$. muelleri from a semiarid region in Pernambuco state, Northeastern Brazil and discussed the classification of a "specialized diet" for this species.

We analyzed the stomach contents of 33 individuals of Dermatonotus muelleri collected in 12 April 2012 during the wet season in a semiarid region, in Exú municipality (3945'20'W, 7³4'31''S), Pernambuco state, Northeastern Brazil. Voucher specimens are housed the herpetological collection of the Universidade Regional do Cariri, being 30 males and three females (URCA-H 2206, 3223,
2701, 3225, 2709, 2203, 1585, 2710, 2207, 1582, 1451, 3212, 2201, 2211, 2215, 2209, 2213, 2210, 2208, 2205, 8653, 8787, 5401, 8651, 5399, 5405, 5402, 5409, 5408, $8652,5400,8650,8646)$. Each stomach was analyzed under a stereo microscope, and the preys registered were identified to the lowest possible taxonomic level (usually order). We measured also the length and width of the intact preys, when they were present in the stomach tract, using a digital caliper (precision $0.01 \mathrm{~mm}$ ). Prey volume was calculated using the Ellipsoid formula: $V=4 / 3 . \pi(\mathrm{L} / 2) .(\mathrm{B} / 2)^{2}$, where $\mathrm{V}=$ volume, $\mathrm{L}=$ length and $\mathrm{W}=$ width (Griffiths and Mylotte, 1987). We used the Relative Importance Index (RII) as a measure of the relative contribution of each prey category (Pinkas et al., 1971). RII $=(\mathrm{F} \%+\mathrm{N} \%+\mathrm{V} \%) / 3$, where $\mathrm{F} \%, \mathrm{~N} \%$ and $\mathrm{V} \%$ are the percentages of prey frequency, number and volume, respectively.

Among the 33 specimens examined, just one individual did not have preys in the stomach contents. The diet of Dermatonotus muelleri was composed of six prey categories, being Isoptera the most abundant item both numerically (95\%), volumetrically (99.7\%), and in frequency (51.2\%). Isoptera also had the highest relative importance index, contributing with $82 \%$ of its diet. Formicidae presented the second-highest frequency (22\%) (Table 1).

We also registered amounts of plant material (frequency of $9.8 \%$ ), and others prey categories, such as Coleoptera (frequency of $4.9 \%$ ), Dermaptera, Ixodida, and Orthoptera (frequency of $2.4 \%$ each one) (Table 1). Regarding the plant material, some studies suggest food items with a

Table 1. Diet of Dermatonotus muelleri from a semiarid region in Pernambuco state, Northeastern Brazil.

\begin{tabular}{crrrr}
\hline Prey Category & N\% & RII & V\% & F\% \\
\hline Isoptera & 95.0 & 82.0 & 99.7 & 51.2 \\
Formicidae & 3.2 & 8.5 & 0.1 & 22.0 \\
Plant material & 0.4 & 3.4 & 0.0 & 9.8 \\
Coleoptera & 0.2 & 1.7 & 0.0 & 4.9 \\
Ixodida & 0.1 & 0.8 & 0.0 & 2.4 \\
Dermaptera & 0.1 & 0.8 & 0.0 & 2.4 \\
Ortoptera & 0.1 & 2.0 & 0.0 & 2.4 \\
Not identified & 0.9 & res & 0.9 & 4.9 \\
\hline
\end{tabular}

$\mathrm{N} \%=$ relative number of prey items; $\mathrm{RII}=$ relative importance index; $\mathrm{V} \%$ = relative volume; and $\mathrm{F} \%=$ relative frequency. 
low frequency of occurrence $(<3.5 \%)$ could have been accidentally ingested during the prey capture or were sporadically available (e.g., Sabagh et al., 2010; Piatti and Souza, 2011). However, Nomura and Rossa-Feres (2011) found that $D$. muelleri can shift the search for prey according to prey distribution. Thus, as the frequency of plant material and Coleoptera occurrences, for example, were $9.8 \%$ and $4.9 \%$, respectively, it is possible that D. muelleri presents an opportunistic diet depending on the availability of food items in the environment.

Previous research on Dermatonotus muelleri diet indicates a specialization in ants and termites (VazSilva et al., 2003; Leite-Filho et al., 2015; Menin et al., 2015; Caldas et al., 2019). Considering that Dermatonotus muelleri presents explosive reproductive behavior (Nomura, 2003), and once the termites are also most abundant in the wet season (Pinheiro et al., 2002), the great number of Isoptera in its stomach content may be attributed to the high abundance of this prey in the environment during this season. On the other hand, herein, we report a wide variety of food items consumed, in the wet season, adding five more types of prey in its diet list. Our results suggest the feeding habits of $D$. muelleri depends on the variety and availability of resources. Thus, the short period of activity of $D$. muelleri, during the reproductive period in semiarid regions, may indicate that opportunistic behavior, including a wide variety of food items, is best for species with explosive reproductive behavior. However, future studies assessing the seasonality and the availability of prey in the environment may respond more precisely to the opportunistic or specialized habits of this species.

Here, we analyzed the Dermatonotus muelleri diet, a species considered specialized in ants and termites, and reported five new prey categories, contributing to a better comprehension about the feeding habits this species from a semiarid region, Northeastern Brazil.

\section{Acknowledgements}

We thank to the Fundação Cearense de Apoio ao Desenvolvimento Científico e Tecnológico (FUNCAP, Proc. 0008-00344.01.13/18) for financial support. R.A.B. and R.W.A. thank Conselho Nacional de Desenvolvimento Científico e Tecnológico - CNPq for the research grant (Proc. 305988/2018-2, 155556/2018-5). We thank Rodrigo Castellari Gonzalez (Museu Nacional do Rio de Janeiro MNRJ/UFRJ) for the English review. We also thank to the Instituto Chico Mendes de Conservação da Biodiversidade (ICMBio) for the collection license (Permit: ICMBio 29613).

\section{References}

BERNARDE, P.S., 2012. Anfibios e répteis: introdução ao estudo da herpetofauna brasileira. 1. ed. Curitiba: Anolis Books, 320 p.

CALDAS, F.L., GARDA, A.A., CAVALCANTI, L.B., LEITEFILHO, E., FARIA, R.G. and MESQUITA, D.O., 2019. Spatial and trophic structure of anuran assemblages in environments with different seasonal regimes in the Brazilian Northeast Region.
Copeia, vol. 107, no. 3, pp. 567-584. http://dx.doi.org/10.1643/ CH-18-109.

DUELLMAN, W.E. and TRUEB, L., 1994. Biology of amphibians. Baltimore: The Johns Hopkins University Press, 670 p.

GRIFFITHS, R.A. and MYLOTTE, V.J., 1987. Microhabitat selection and feeding relations of smooth and warty newts, Triturus vulgaris and T. cristatus, at an upland pond in mid-Wales. Ecography, vol. 10, no. 1, pp. 1-7. http://dx.doi.org/10.1111/j.1600-0587.1987. tb00731.x.

LEITE-FILHO, E., VIEIRA, W.L.S., SANTANA, G.G., ELOI, F.J. and MESQUITA, D.O., 2015. Structure of a Caatinga anuran assemblage in Northeastern Brazil. Neotropical Biology and Conservation, vol. 10, no. 2, pp. 63-73. http://dx.doi.org/10.4013/ nbc.2015.102.02.

MENIN, M., SANTOS, R.S., BORGES, R.E. and PIATTI, L., 2015. Notes on the diet of seven terrestrial frogs in three agroecosystems and forest remnants in Northwestern São Paulo State, Brazil. Herpetology Notes, vol. 8, no. 1, pp. 401-405.

NOMURA, F. and ROSSA-FERES, D.C., 2011. The frog Dermatonotus muelleri (Boettger 1885) (Anura Microhylidae) shifts its search tactics in response to two different prey distributions. Ethology Ecology and Evolution, vol. 23, no. 4, pp. 318-328. http://dx.doi.org/10.1080/03949370.2011.573810.

NOMURA, F., 2003. Ecologia reprodutiva e comportamento de forrageio e escavação de Dermatonotus muelleri (Boettger, 1885) (Anura, Microhylidae). Rio Claro: Universidade Estadual Paulista, 95 p. Dissertação de Mestrado em Biologia Animal.

NOMURA, F., ROSSA-FERES, D.C. and LANGEANI, F., 2009. Burrowing behavior of Dermatonotus muelleri (Anura, Microhylidae) with reference to the origin of the burrowing behavior of Anura. Journal of Ethology, vol. 27, no. 1, pp. 195201. http://dx.doi.org/10.1007/s10164-008-0112-1.

PACHECO, E.O., FERREIRA, V.G. and CARVALHO, R.M.H., 2017. Diet of Boana albopunctata (Anura: Hylidae) in an Atlantic Forest fragment of southeastern Brazil. Phyllomedusa, vol. 16, no. 1, pp. 57-62. http://dx.doi.org/10.11606/issn.2316-9079. v16ilp57-62.

PIATTI, L. and SOUZA, F.L., 2011. Diet and resource partitioning among anurans in irrigated rice fields in Pantanal, Brazil. Brazilian Journal of Biology = Revista Brasileira de Biologia, vol. 71, no. 3, pp. 653-661. http://dx.doi.org/10.1590/S1519-69842011000400009. PMid:21881788.

PINHEIRO, F., DINIZ, I.R., COELHO, D. and BANDEIRA, M.P.S., 2002. Seasonal pattern of insect abundance in the Brazilian cerrado. Austral Ecology, vol. 27, no. 2, pp. 132-136. http://dx.doi. org/10.1046/j.1442-9993.2002.01165.x.

PINKAS, L., OLIPHANT, M.S. and IVERSON, I.L.K., 1971. Food habits of Albacore, Bluefin Tuna, and Bonito in California waters. Fish Bulletin, vol. 152, pp. 1-105.

SABAGH, L.T., FERREIRA, V.L. and ROCHA, C.F.D., 2010. Living together, sometimes feeding in a similar way: the case of the syntopic hylid frogs Hypsiboas raniceps and Scinax acuminatus (Anura: Hylidae) in the Pantanal of Miranda, Mato Grosso do Sul State, Brazil. Brazilian Journal of Biology = Revista Brasileira de Biologia, vol. 70, no. 4, pp. 955-959. http://dx.doi.org/10.1590/ S1519-69842010000500006. PMid:21180899.

VAZ-SILVA, W., SILVA, H.L.R. and SILVA-JÚNIOR, N.J., 2003. Dermatonotus muelleri (Mueller's Narrow-mouthed Frog). Diet. Herpetological Review, vol. 34, no. 4, pp. 357. 